\title{
SYNTHESIS AND CHARACTERIZATION OF COPPER COMPLEXES: INTERACTION OF METALLIC CARBOXYLATES WITH 1,3-THIAZOLE LIGAND
}

\author{
GLORIA V. SEGUEL*, BERNABÉ L. RIVAS, J. GUILLERMO CONTRERAS \\ Facultad de Ciencias Químicas, Universidad de Concepción, Casilla 160-C, Concepción, Chile \\ (Received: May 30, 2013 - Accepted: September 9, 2013)
}

\begin{abstract}
Complexes were synthesized from aspirinate of $\mathrm{Cu}(\mathrm{II})$ and acetate of $\mathrm{Cu}(\mathrm{II})$ dihydrated with the ligand 1,3-thiazole and were characterized through elemental analysis, magnetic moment, FT-IR spectroscopy, and thermogravimetric analysis. Moreover, semiempirical structural PM6 of both compounds were carried out.

Ligand 1,3-thiazole coordinates with the $\mathrm{Cu}(\mathrm{II})$ ions through the nitrogen without break the dimeric unit $\mathrm{Cu}_{2}(\mathrm{RCOO})_{4}$ To coordinate with the aspirinate of $\mathrm{Cu}(\mathrm{II})$, the ligand must to break tridimensional arrangement and to coordinate with the acetate of $\mathrm{Cu}(\mathrm{II})$ dihydrated, it replaced the water molecules. In both compounds, $\mathrm{Cu}_{2}(\operatorname{asp})_{4}(\mathrm{Tz})_{2}$ and $\mathrm{Cu}_{2}(\text { acetate })_{4}(\mathrm{Tz})_{2}$, the $\mathrm{PM} 6$ calculations corresponding to the $\mathrm{Cu}-\mathrm{Cu}$ distances in the dimeric unit $\mathrm{Cu} \mathrm{R}_{2}(\mathrm{RCOO})_{4}$ presents a small difference $0.03 \mathrm{~A}^{\circ}$, but the magnetic moments are very different. The complex with aspirinate presents a magnetic moment of $1.79 \mathrm{M} . \mathrm{B}$ and that with acetate is $1.4 \mathrm{MB}$.
\end{abstract}

Keywords: metallic aspirinates, metallic acetates, 1,3-thiazole

\section{INTRODUCTION}

Aspirine, acetil salicylic acid, it is very well known as antipiretic, analgesic, and anti-inflammatory agent [1]. It has been reported that the complex $\mathrm{Cu}_{2}$ (aspirine) $)_{4}$ also shows interesting properties such as anticancerogenic, antimutagenic, bactericide, anticonvulsivant, and as potent antioxidant agent in biological systems [2]. It has been demonstrated that it is a better antioxidant than the salicylate of $\mathrm{Cu}(\mathrm{II})$ and acetate of $\mathrm{Cu}(\mathrm{II})$ [3].

The compound $\mathrm{Cu}_{2}$ (aspirine) $)_{4}$ possesses a dimeric structure which is similar to that found in acetate of $\mathrm{Cu}$ (II) monohydrated. In both cases the two copper atoms are bridged by carboxylate groups $[4,5]$. The $\mathrm{Cu}-\mathrm{Cu}$ distance in $\mathrm{Cu}_{2}$ (acetate) ${ }_{4} \cdot 2 \mathrm{H}_{2} \mathrm{O}$ is $2.63 \mathrm{~A}^{\circ}$ and shows an non usual magnetic moment of 1.4 M.B. The antiferromagnetism has been explained by several authors through different mechanisms; one of them suggested a super exchange mechanism through the carboxylate groups [6-8].

Aspirinate of $\mathrm{Cu}(\mathrm{II})$ Figure 1 forms a polymeric chain where the $\mathrm{Cu}_{2}$ (aspirine) $)_{4}$ units are associated via $\mathrm{Cu}-\mathrm{O}$ (acetyl) bonds, with an average distance $\mathrm{Cu}-\mathrm{O}$ of $2.963 \mathrm{~A}^{\circ}$. The distance $\mathrm{Cu}-\mathrm{Cu}$ is $2.617 \mathrm{~A}^{\circ}$ [9] and a magnetic moment of 2.04 M.B. has been reported [3].

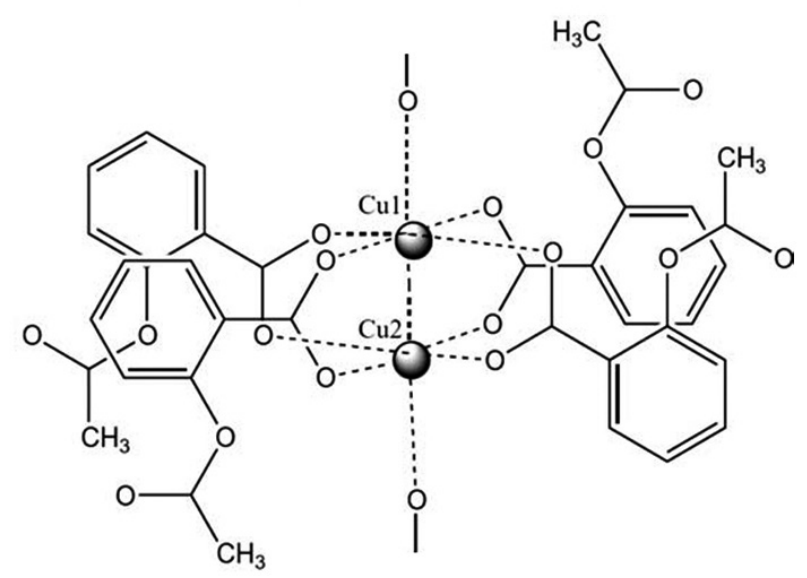

Figure 1. Structure of aspirinate of $\mathrm{Cu}(\mathrm{II})$.

The pharmacological activity increases by the presence of ligands which coordinate through nitrogen donor atoms such as imidazoles, diimines, and pyridines. Mononuclear copper(II) complexes with nitrogen containing ligands i.e. bis(aspirinate)bis(2-methylimidazole) copper(II), $\mathrm{Cu}(\mathrm{asp})_{2}(2-\mathrm{MeIm})_{2}$, have prepared by the reaction of 2-methylimidazole with binuclear $\mathrm{Cu}_{2}(\mathrm{asp})_{4}$.
[10]. On the other hand, the dinuclear compounds $\left[\mathrm{Cu}_{2}(\text { aspirinate })_{4}(\mathrm{~L})_{2}\right](\mathrm{L}=$ DMSO, DMF) have also been prepared and studied with regard and to their anticonvulsivant activities [11].

The thiazoles and their derivatives have a great biological importance as constituents of biomolecules like antibiotics. The pharmacological activities and their coordination properties are important features to prepare metal complexes with potential therapeutical activity or as model of metal-enzyme [13-16].

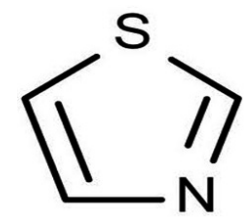

Figure 2 : Structure of 1,3-thiazole.

Thiazole (Figure 2) has both nitrogen and sulfur atoms as possible donor sites, and whereas the majority of complexes have been found to be nitrogen bonded, a case of sulfur coordination has been postulated [14].

The aim of this work is to study the interaction of 1,3-thiazole and $\mathrm{Cu}(\mathrm{II})$ complexes, $\mathrm{Cu}_{2}(\mathrm{asp})_{4}$ and $\mathrm{Cu}_{2}(\text { acetate })_{4} \cdot 2 \mathrm{H}_{2} \mathrm{O}$.

\section{EXPERIMENTAL}

Materials

The metal salts, $\mathrm{CuSO}_{4}, \mathrm{SH}_{2} \mathrm{O}_{2}$ (acetate) $)_{4} \cdot 2 \mathrm{H}_{2} \mathrm{O}$ and $\mathrm{NaHCO}_{3}$ were analytical grade (Merck). 1,3-thiazole was purchased from Aldrich.

Synthesis of copper(II) aspirinate $\mathrm{Cu}_{2}(\mathbf{a s p})_{4}$

It was synthesized according to the literature [1,9]-The aspirine $(1,0 \mathrm{~g})$ was suspended in water and dissolved by adding slowly an aqueous solution of sodium bicarbonate $(0,29 \mathrm{~g})$, the aspirine must be in excess. There is an evolution of gas, and after the reaction finish, it was filtered. An aqueous solution of $\mathrm{CuSO}_{4} \cdot 5 \mathrm{H}_{2} \mathrm{O}(0,7 \mathrm{~g})$ was prepared. Both are mixed under slow stirring. Immediately, the formation of a blue precipitate was observed. The stirring was continued for couple of min and then it was filtered and washed with water.

Synthesis of $\mathrm{Cu}_{2}(\operatorname{asp})_{4} \cdot(\mathrm{Tz})_{2}$ and $\mathrm{Cu}_{2}(\text { acetate })_{4}(\mathrm{Tz})_{2}$.

The complexes $\mathrm{Cu}_{2}(\mathrm{asp})_{4} \cdot(\mathrm{Tz})_{2}$ and $\mathrm{Cu}_{2}$ (acetate $)_{4}(\mathrm{Tz})_{2}$ were synthesized from $\mathrm{Cu}_{2}(\mathrm{asp})_{4}$ and $\mathrm{Cu}_{2}$ (acetate) $)_{4} \cdot 2 \mathrm{H}_{2} \mathrm{O}$, respectively.

The compounds of $\mathrm{Cu}(\mathrm{II})$ were suspended in ethanol and an stoichiometric amount of 1,3-thiazole was added. After several hours under stirring a change of color of the solid fraction was observed. It was filtrated, washed with ethanol, and dried at oven at $50^{\circ} \mathrm{C}$. A yield of $65 \%$ was obtained. 
$\mathrm{Cu}_{2}(\operatorname{asp})_{4} \cdot(\mathrm{Tz})_{2}$

Elemental analysis: (Found: Cu: $12.7 \%$, N: $4.4 \%$, C: 44.2\%, H:3.5 \%.

Calcd.: $\mathrm{Cu}: 12.5 \%$, N: $2.8 \%$, C: $49.7 \%$, H: $3.7 \%$ ).

$\mathrm{Cu}_{2}$ (acetate) ${ }_{4}(\mathrm{Tz})$

Elemental analysis: (Found: Cu: $23.4 \%$, N: $5.7 \%$, C: $32.5 \%$, H: $3.3 \%$.

Calcd.: Cu: $23.8 \%$, N: $5.2 \%$, C: $31.5 \%$, H: $3.4 \%$

Measurements

$\mathrm{Cu}$ (II) was analyzed by atomic absorption spectrometry with a Perkin Elmer model $5300 \mathrm{DV}$ and the elemental analysis C,H,N in an EA 1108 Analyzer Elemental, Fision Instruments.

FT IR spectra were recorded on a Magna Nicolet 550 and Nicolet Nexsus spectrophotometers. The magnetic susceptibility measurements were performed at room temperature on a Sherwood Auto Magnetic Susceptibility Balance by the Gouy method using $\mathrm{Hg}\left[\mathrm{Co}(\mathrm{SCN})_{4}\right]$ as the calibration standard . From the observed susceptibility, the magnetic moment, $\mu_{\text {eff }}$ was calculated using the following formula: $\mu_{\text {eff }}=2.824 \sqrt{X_{M} T}$. The diamagnetic contribution due to the core electrons was estimated using Pascal constants and subtracted from the experimental values.

Thermogravimetric analysis was carried out in a Netzsch model TG 209 F1, Iris. $\mathrm{N}_{2(\mathrm{~g})}$ of high quality was used with a flux of $250 \mathrm{~mL} / \mathrm{min}$, heating rate was $10^{\circ} \mathrm{C} / \mathrm{min}$ in a temperature range from $30^{\circ} \mathrm{C}$ to $550^{\circ} \mathrm{C}$.

Quantum Chemical Calculations

PM6 semi-empirical calculations were carried out using GAUSSIAN98 package. The compounds were created graphically with support of the HyperChem Program. It was optimized by molecular mechanical and subsequently by the PM6 calculation method.

\section{RESULTS AND DISCUSSION}

For the aspirinate of $\mathrm{Cu}(\mathrm{II})$ the $\mathrm{Cu}_{2}(\operatorname{asp})_{4}$ units are forming a polymeric chain and the coordination of 1,3-thiazole group through the nitrogen to each $\mathrm{Cu}$ (II) ion in axial position obtaining as product the $\mathrm{Cu}_{2}(\mathrm{asp})_{4}(\mathrm{Tz})_{2}$ complex. (Figure 3). The ligand break the intermolecular $\mathrm{Cu}-\mathrm{O}$ (acetyl).

To react the 1,3-thiazole with $\mathrm{Cu}_{2}(\text { acetate })_{4} \cdot 2 \mathrm{H}_{2} \mathrm{O}$, changing the water molecules and coordinating to the $\mathrm{Cu}(\mathrm{II})$ ions through the nitrogen atoms yielding $\mathrm{Cu}_{2}\left(\mathrm{CH}_{3} \mathrm{COO}\right)_{4}(\mathrm{Tz})_{2}$ complex. (Figure 4$)$.

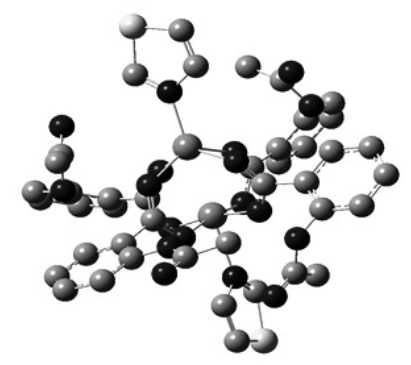

Figure 3: $\mathrm{PM} 6$ calculated structure of $\mathrm{Cu}_{2}(\mathrm{asp})_{4}(\mathrm{Tz})_{2}$

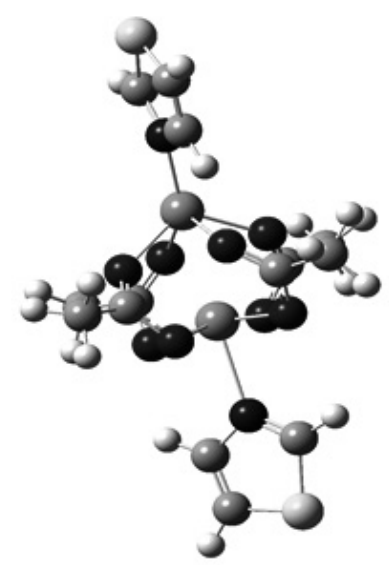

Figure 4: $\mathrm{PM} 6$ calculated structure of $\mathrm{Cu}_{2}\left(\mathrm{CH}_{3} \mathrm{CO0}\right)_{4}(\mathrm{Tz})_{2}$
Table 1. FT-IR absorption signals $\left(\mathrm{cm}^{-1}\right)$ for acetyl salicylic acid and complexes.

\begin{tabular}{|c|c|c|c|}
\hline$v\left(\mathbf{c m}^{-1}\right)$ & Aspirine & $\mathbf{C u}_{\mathbf{2}}(\mathbf{a s p})_{\mathbf{4}}$ & $\left.\mathbf{C u}_{\mathbf{2}}(\mathbf{a s p})_{\mathbf{4}} \mathbf{( T z}\right)_{\mathbf{2}}$ \\
\hline$v(\mathrm{C}=\mathrm{O})$ acetyl & 1759 & 1761,1725 & 1750 \\
\hline$v\left(\mathrm{COO}^{-}\right) \mathrm{as}$ & 1689 & 1618 & 1608 \\
\hline$v\left(\mathrm{COO}^{-}\right) \mathrm{s}$ & 1455 & 1408 & 1373 \\
\hline$v(\mathrm{C}=\mathrm{N})$ thiazole & & & 1449 \\
\hline
\end{tabular}

In the FTIR spectrum, (Table 1) the stretching vibration of acetyl group in the free aspirine is observed at $1759 \mathrm{~cm}^{-1}$, and in the $\mathrm{Cu}$ (II) aspirinate are observed two absorption bands at 1761 and $1725 \mathrm{~cm}^{-1}$, and in the complex with the thiazole only one at $1750 \mathrm{~cm}^{-1}$. The symmetric and unsymmetric stretching vibrations of carboxylic acid group present in the aspirine at 1689 and 1455 $\mathrm{cm}^{-1}$ are shifted at lower frequency by effect of the coordination. In the $\mathrm{Cu}(\mathrm{II})$ aspirinate are shifted at 1618 and $1408 \mathrm{~cm}^{-1}$ and those aspirinates and thiazole complexes are shifted at 1608 and $1373 \mathrm{~cm}^{-1}$. In the spectrum of $\mathrm{Cu}_{2}(\mathrm{asp})_{4}(\mathrm{Tz})_{2}$ complex, it is observed an absorption band at $1449 \mathrm{~cm}^{-1}$ attributed to stretching vibration $v(\mathrm{C}=\mathrm{N})$ of thiazole group.

Table 2. FT-IR absorption signals $\left(\mathrm{cm}^{-1}\right)$ for $\mathrm{Cu}_{2}\left(\mathrm{CH}_{3} \mathrm{COO}\right)_{4} \cdot 2 \mathrm{H}_{2} \mathrm{O}$ and $\mathrm{Cu}_{2}\left(\mathrm{CH}_{3} \mathrm{COO}\right)_{4}(\mathrm{Tz})_{2}$

\begin{tabular}{|c|c|c|}
\hline$v\left(\mathbf{c m}^{-1}\right)$ & $\mathbf{C u}_{\mathbf{2}}\left(\mathbf{C H}_{3} \mathbf{C O O}\right)_{4} \cdot \mathbf{2 H}_{2} \mathbf{O}$ & $\left.\mathbf{C u}_{\mathbf{2}}\left(\mathbf{C H}_{\mathbf{3}} \mathbf{C O O}\right)_{\mathbf{4}} \mathbf{( T z}\right)_{2}$ \\
\hline$v(\mathrm{COO})$ as & 1608 & 1620 \\
\hline$v\left(\mathrm{COO}^{-}\right)$as & 1440 & 1436 \\
\hline$v(\mathrm{C}=\mathrm{N})$ thiazole & & 1496 \\
\hline
\end{tabular}

The FTIR spectrum of $\mathrm{Cu}_{2}\left(\mathrm{CH}_{3} \mathrm{COO}\right)_{4} \cdot 2 \mathrm{H}_{2} \mathrm{O}$ (Table 2) shows the antisymmetric and symmetric stretching vibrations of the acetate group at 1608 and $1440 \mathrm{~cm}^{-1}$ [17]. The spectrum of the complex $\mathrm{Cu}_{2}\left(\mathrm{CH}_{3} \mathrm{COO}\right)_{4}(\mathrm{Tz})_{2}$ shows the same absorption bands at 1620 and $1436 \mathrm{~cm}^{-1}$ and the strength vibrations $v$ $(\mathrm{C}=\mathrm{N})$ from thiazole group at $1496 \mathrm{~cm}^{-1}$.

\section{Magnetic measurements}

For the aspirinate of copper(II) different magnetic moments from 2.0 up to 1.35 M.B have been reported $[3,8]$.

In the current work, the magnetic moments for the aspirinate of copper(II) and the complex with 1,3-thiazole were determined from the experimental data doing the corresponding corrections of the diamagnetism, yielding, 1.77 and 1.79 M.B respectively.

For those $\mathrm{Cu}_{2}\left(\mathrm{CH}_{3} \mathrm{COO}\right)_{4} \cdot 2 \mathrm{H}_{2} \mathrm{O}$ and $\mathrm{Cu}_{2}\left(\mathrm{CH}_{3} \mathrm{COO}\right)_{4}(\mathrm{Tz})_{2}$ complexes the magnetic moments were determined and the value for both was 1.4 M.B.

Hermler and Meyer have reported for the $\mathrm{Cu}_{2}\left(\mathrm{CH}_{3} \mathrm{COO}\right)_{4}$ (1,3-benzothiazole $)_{2}$ complex a value for the magnetic moment 1.42 M.B [19].

\section{Thermogravimetric analysis}

TGA of $\mathrm{Cu}_{2}(\mathrm{asp})_{4}(\mathrm{Tz})_{2}$ complex shows the weight loss corresponding to the thiazole groups $(16.7 \%)$ at $128^{\circ} \mathrm{C}$, aspirinate group $\left((17 \%)\right.$ at $161^{\circ} \mathrm{C}$, a second aspirinate $(17 \%)$ at $241^{\circ} \mathrm{C}$, and then the loss of the other aspirinate groups (Figure 5).

The sequence of decomposition reactions as deduced from TGA studies are summarized below:

$$
\begin{array}{llll}
\mathrm{Cu}_{2}(\text { asp })_{4}(\mathrm{Tz})_{2} & \rightarrow & \mathrm{Cu}_{2}(\text { asp })_{4} & +2 \mathrm{Tz} \\
\left.\mathrm{Cu}_{2} \text { (asp }\right)_{4} & \rightarrow & \mathrm{Cu}_{2}(\text { asp })_{3} & + \text { asp } \\
\left.\mathrm{Cu}_{2} \text { (asp }\right)_{3} & \rightarrow & \mathrm{Cu}_{2}(\text { asp })_{2} & + \text { asp } \\
\left.\mathrm{Cu}_{2} \text { (asp }\right)_{2} & \rightarrow & \left.\mathrm{Cu}_{2} \text { (asp }\right)+ \text { asp } \\
\left.\mathrm{Cu}_{2} \text { (asp }\right) & \rightarrow & 2 \mathrm{CuO}+\text { asp }
\end{array}
$$




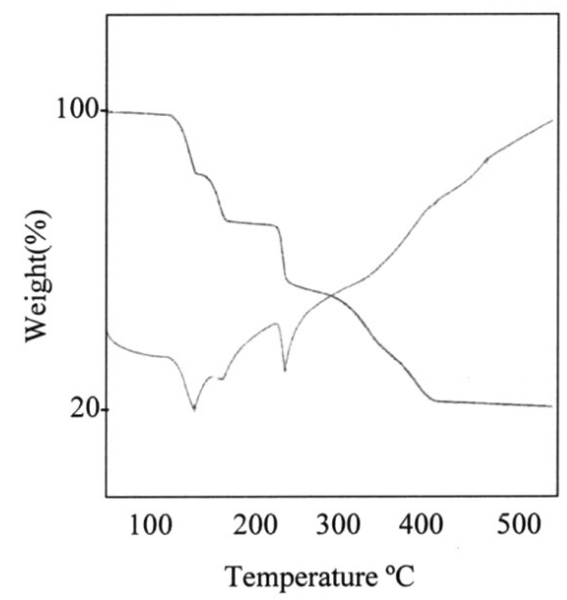

TGA of $\mathrm{Cu}_{2}$ (acetate) $)_{4}(\mathrm{Tz})_{2}$ shows the loss of thiazole group (32\%) at $165^{\circ} \mathrm{C}$ and the weight loss of four acetate groups $(44 \%)$ at $272^{\circ} \mathrm{C}$.

The sequence of decomposition reactions as deduced from TGA studies are summarized below:

$$
\begin{aligned}
& \mathrm{Cu}_{2}(\text { acetate })_{4}(\mathrm{Tz})_{2} \quad \rightarrow \quad \mathrm{Cu}_{2}(\text { acetate })_{4}+2 \mathrm{Tz} \\
& \left.\mathrm{Cu}_{2} \text { (acetate }\right)_{4} \quad \rightarrow \quad 2 \mathrm{CuO} \quad+\text { 4Acetates }
\end{aligned}
$$

For both compounds, semiempiric structural calculations PM6 were carried and they were compared with reported crystalline structures [7,9]. To analyze the PM6 data of $\mathrm{Cu}_{2}(\operatorname{asp})_{4}(\mathrm{Tz})_{2}$ complex, (Table 3) PM6 calculations for the complex $\mathrm{Cu}_{2}(\mathrm{asp})_{4}(\mathrm{DMF})_{2}$ were carried out considering that the crystalline structure was reported [11]. PM6 calculations of both compounds show only small differences.

Figure 5: TGA and DTG curves of $\mathrm{Cu}_{2}(\mathrm{asp})_{4}(\mathrm{Tz})_{2}$

\begin{tabular}{|c|c|c|c|c|}
\hline & Crystal structure ${ }^{a, b}$ & & PM6 & \\
\hline Parameter & $\mathrm{Cu}_{2}(\operatorname{asp})_{4}$ & $\mathrm{Cu}_{2}(\operatorname{asp})_{4}(\mathrm{DMF})_{2}$ & $\mathrm{Cu}_{2}(\operatorname{asp})_{4}(\mathrm{DMF})_{2}$ & $\mathrm{Cu}_{2}(\operatorname{asp})_{4}(\mathrm{Tz})_{2}$ \\
\hline \multicolumn{5}{|l|}{ Length of bond $\left(\mathrm{A}^{\circ}\right)$} \\
\hline $\mathrm{Cu}-\mathrm{Cu}$ & 2.617 & 2.6154 & 2.771 & 2.779 \\
\hline \multirow[t]{2}{*}{$\mathrm{Cu}-\mathrm{O}$ (basal) } & 1.963 & 1.9533 & 2.024 & 2.041 \\
\hline & & 1.9711 & 1.831 & 1.817 \\
\hline \multirow[t]{2}{*}{$\mathrm{Cu}-\mathrm{O}($ axial) } & 2.241 & 2.1540 & 2.069 & \\
\hline & & & 2.009 & \\
\hline \multirow[t]{2}{*}{$\mathrm{Cu}-\mathrm{N}$} & & & & 2.047 \\
\hline & & & & 2.339 \\
\hline \multirow[t]{2}{*}{ O-C(carboxylate) } & 1.26 & 1.256 & 1.244 & 1.235 \\
\hline & & 1.268 & 1.311 & 1.311 \\
\hline \multicolumn{5}{|l|}{ Bond angle $\left(^{\circ}\right)$} \\
\hline \multirow[t]{2}{*}{$\mathrm{Cu}-\mathrm{O}-\mathrm{C}$} & 120.7 & 119.92 & 102.9 & 123.3 \\
\hline & 125.9 & 125.15 & 141.9 & 137.2 \\
\hline \multirow[t]{2}{*}{$\mathrm{O}-\mathrm{C}-\mathrm{O}$} & 125.0 & 125.69 & 141.9 & 114.3 \\
\hline & 126.0 & 125.76 & 120.8 & 122.5 \\
\hline
\end{tabular}

Table 3: Selected PM6 structural parameters of $\mathrm{Cu}_{2}(\operatorname{asp})_{4}(\mathrm{Tz})_{2}$

Ref.7 $\quad$ b) Ref.9

PM6 calculations (Table 4) complexes of $\mathrm{Cu}_{2}(\text { acetate })_{4}(\mathrm{Tz})_{2}$ and $\mathrm{Cu}_{2}$ (acetate $)_{4} \cdot 2 \mathrm{H}_{2} \mathrm{O}$ were carried out for $\mathrm{Cu}_{2}(\text { acetate })_{4} \cdot 2 \mathrm{H}_{2} \mathrm{Othat}$ was reported the crystalline structure for other authors [4]. PM6 calculations show an important difference in the $\mathrm{Cu}-\mathrm{Cu}$ distances.

\begin{tabular}{|c|c|c|c|}
\hline & Crystal structure $^{a}$ & PM6 & \\
\hline Parameter & $\mathrm{Cu}_{2}$ (acetate) $)_{4} \cdot 2 \mathrm{H}_{2} \mathrm{O}$ & $\mathrm{Cu}_{2}$ (acetate) $)_{4} \cdot 2 \mathrm{H}_{2} \mathrm{O}$ & $\mathrm{Cu}_{2}(\text { acetate })_{4}(\mathrm{Tz})_{2}$ \\
\hline \multicolumn{4}{|l|}{ Length of bond $\left(\mathrm{A}^{\circ}\right)$} \\
\hline $\mathrm{Cu}-\mathrm{Cu}$ & 2.64 & 2.720 & 2.760 \\
\hline \multirow[t]{2}{*}{$\mathrm{Cu}-\mathrm{O}$ (basal) } & 2.20 & 1.815 & 1.823 \\
\hline & & 2.010 & 2.048 \\
\hline \multirow[t]{2}{*}{$\mathrm{Cu}-\mathrm{O}($ axial $)$} & 1.96 & 2.098 & \\
\hline & & 2.147 & \\
\hline \multirow[t]{2}{*}{$\mathrm{Cu}-\mathrm{N}$} & & & 2.032 \\
\hline & & & 2.370 \\
\hline \multirow[t]{2}{*}{ O-C(carboxylate) } & 1.29 & 1.242 & 1.250 \\
\hline & 1.34 & 1.315 & 1.310 \\
\hline \multicolumn{4}{|l|}{ Bond angle $\left(^{\circ}\right)$} \\
\hline \multirow[t]{2}{*}{$\mathrm{Cu}-\mathrm{O}-\mathrm{C}$} & & 103.6 & 105.7 \\
\hline & & 142.7 & 131.0 \\
\hline \multirow[t]{2}{*}{$\mathrm{O}-\mathrm{C}-\mathrm{O}$} & 116.0 & 114.7 & 115.9 \\
\hline & & 121.8 & 116.8 \\
\hline
\end{tabular}

Table 4. Selected PM6 structural parameters of $\mathrm{Cu}_{2}(\text { acetate })_{4} \cdot 2 \mathrm{H}_{2} \mathrm{O}$ and $\mathrm{Cu}_{2}$ (acetate $)_{4}(\mathrm{Tz})_{2}$

a)Ref. [2]. 


\section{CONCLUSIONS}

Accordingly to the experimental results it can be concluded that in both complexes, the dimeric $\mathrm{Cu}_{2}(\mathrm{RCOO})_{4}$ does not break and the 1,3-thiazole ligand coordinates through the nitrogen.

The coordination of the ligand does not produce strong changes in the structure of the dimeric unit $\mathrm{Cu}_{2}(\mathrm{RCOO})_{4}$.

The distances $\mathrm{Cu}-\mathrm{Cu}$ in the aspirinates and acetates of $\mathrm{Cu}(\mathrm{II})$ are very similar, however, the magnetic moments are very different.

$\mathrm{Cu}-\mathrm{Cu}$ distances of aspirinates are lower than those acetates of $\mathrm{Cu}(\mathrm{II})$, however, the magnetic moments of aspirinates are higher than those of acetates of $\mathrm{Cu}(\mathrm{II})$.

It can suggest that the $\mathrm{Cu}-\mathrm{Cu}$ distance in the acetate of $\mathrm{Cu}(\mathrm{II})$ is not the more important effect for the not usual value 1.4 M.B obtained.

\section{ACKNOWLEDGEMENTS}

The authors thank to Vicerrectoria de Investigación y Desarrollo, Universidad de Concepción (Grant No 211.021.032-1.0) and PIA (Anillo ACT-130).

\section{REFERENCES}

1. C. Davison, Ann. N.Y. Acad. Sci.,179, 249 (1971).

2. Z.Q. Shen, Y. Liang, Z.H. Chen, W.P. Liu, L. Duan, J. Pharm, Pharmacol., 50,1275 (1998)
3. T. Fujimori, S. Yamada, H. Yasui, H. Sa kurai,Y. In, T. Ishido, J. Biol. Inorg. Chem., 10, 831(2005).

4. J.N. van Nieckerk, F.R.L. Schoening, Acta Cryst., 6, 227 (1953).

5. G.V. Seguel, B.L. Rivas, Y. Moreno, O. Peña, Transition Metal Chem., 32, $1106(2007)$

6. M. Kato, H.B. Jonassen, J.C. Fanning, Chem. Rev. 64, 99 (1964).

7. P.J. Hay, J.C. Thibeault, R. Hoffmann, J. Am. Chem. Soc., 97, 4884 (1975).

8. D.M.L. Goodgame, N.H. Hill, D.F. Marsham, A.C. Skapski,M.L. Smart, P.G.H. Troughton, Chem. Commun. 629 (1969).

9. L. Manojlovic-Muir, Acta Cryist., B29, 2033 (1973).

10. A. Latif Abuhijleh, Inorg. Chem. Comm. 14,759 (2011).

11. B. Viossat, J-C. Daran, G. Savouret, G. Morgant, F.T. Greenway, N-H. Dung, V. A. Pham-Tran, J. R.J.Sorenson, J. Inorg. Biochem. 96, 375 (2003).

12. J. E. Weder, C. T. Dillon, T. W. Hambley, B. J. Kennedy, P. A. Lay, J. R. Biffin, H. L. Regtop, N. M. Davies, Coord. Chem. Rev. 232, 95 (2002).

13. A. Usman, H.Fun, S. Chantraptomma, Acta Cyst. 59, m41, (2003).

14. J.A. Weaver, P. Hambright, P.T. Talbert, E. Kang, A. N. Thorpe, Inorg. Chem. 9(2), 268 (1970).

15. E. J. Duff, M. N. Hughes, K. J. Rutt, J. Chem. Soc.(A),2354 (1968).

16. W. J.Rilbeck, A. E. Underhill, J. Chem. Soc. (A) 757 (1967).

17. B.L.Rivas, G.V.Seguel, Polyhedron, 18, 2511(1999)

18. J.R.Allan, J. Gavin, J. Thermal Anal. 18, 263 (1980).

19. J. Hermle, G.Meyer, Acta Cryst. E67, m1089 (2011). 